Agnethe Siquans

\title{
Anti-Jewish Polemic and Jewish Bible Interpretation: Two Examples from Origen and Ephrem the Syrian
}

\section{Introduction}

Anti-Jewish polemic, sometimes very vehement and insulting, can be found in various writings of the patristic era: not only in treatises such as Adversus Iudaeos or so-called "dialogues" between a Christian and a Jew but also in collections of testimonies, homilies, didactic works, and biblical commentaries. ${ }^{1}$ Yet even with the frequency of anti-Jewish polemic in these writings, patristic interpreters of the Bible refer to Jewish sources of information, as do Origen and Jerome, or their biblical interpretation displays striking parallels to various forms of Jewish interpretation. ${ }^{2}$ Origen, for instance, owes much to Philo, and the writing of Ephrem the Syrian appears partly like a midrash. These parallels have often

1 There are many studies on early Christian anti-Judaism, and there was and is vivid discussion about the nature of Christian anti-Jewish polemic. To name just a few important studies: S. Krauss and W. Horbury, The Jewish-Christian Controversy: From the Earliest Times to 1789: Vol. 1, History (Tübingen: Mohr Siebeck, 1995); J. M. Lieu, Image and Reality: The Jews in the World of the Christians in the Second Century (Edinburgh: T\&T Clark, 1996); S.E. Porter and B. W. R. Pearson, Christian-Jewish Relations through the Centuries (Sheffield: Sheffield Academic, 2000); E. P. Sanders, Jewish and Christian Self-Definition, 3 vols. (Philadelphia: Fortress, 1980 -1983); H. Schreckenberg, Die christlichen Adversus-Judaeos-Texte und ihr literarisches und historisches Umfeld (1.-11. Jahrhundert) (Frankfurt am Main: Peter Lang, 1995); M. Simon, Verus Israel: A Study of the Relations between Christians and Jews in the Roman Empire (135425), trans. H. McKeating (Oxford: Oxford University Press, 1986).

2 For this topic, see E. Grypeou and H. Spurling, eds., The Exegetical Encounter between Jews and Christians in Late Antiquity (Leiden: Brill, 2009); M. Hirshman, A Rivalry of Genius: Jewish and Christian Biblical Interpretation in Late Antiquity, trans. Batya Stein (Albany: State University of New York Press, 1996); W. Horbury, Jews and Christians in Contact and Controversy (Edinburgh: T\&T Clark, 1998); A. Kamesar, "Rabbinic Midrash and Church Fathers," in Encyclopaedia of Midrash: Biblical Interpretation in Formative Judaism, ed. J. Neusner and A. J. Avery-Peck (Leiden: Brill, 2005), 20-40; E. Kessler, "The Exegetical Encounter between the Greek Church Fathers and the Palestinian Rabbis," Studia Patristica 34 (2001): 395-412; G. Stemberger, "Exegetical Contacts between Christians and Jews in the Roman Empire," in Hebrew Bible/Old Testament: The History of Its Interpretation, vol. 1: From the Beginnings to the Middle Ages (until 1300), part 1: Antiquity, ed. M. Sæbø, (Göttingen: Vandenhoeck \& Ruprecht, 1996), 569-86; B. L. Visotzky, Fathers of the World: Essays in Rabbinic and Patristic Literatures (Tübingen: Mohr, 1995).

Ә OpenAccess. (C) 2020 Agnethe Siquans, published by De Gruyter. (cc)BY-NC-ND This work is licensed under the Creative Commons Attribution-NonCommercial-NoDerivatives 4.0 License.

https://doi.org/10.1515/9783110671773-005 
been noticed and explained in different manners. ${ }^{3}$ In particular, however, one question stands out: how is it possible that authors simultaneously display anti-Judaism, ${ }^{4}$ on the one hand, and interpret biblical texts in a "Jewish" way or use "Jewish" methods of interpretation, on the other hand? Obviously, such apparent discrepancies were not perceived as such by the ancient writers or perhaps were perceived differently. Mono-causal and oversimplified explanations do not fit the historical reality of Jewish-Christian relations in late antiquity and the multiplicity of the literary sources. Judith Lieu, for example, aptly points out the necessity of a "detailed mapping of the complex interplay of individual personalities, situations, theological traditions and literary forms which make up the early Christian responses to and constructions of Judaism." ${ }^{5}$ In an exemplary study, Lieu shows that several parameters overlap and interplay: "While it would be wrong to deny any contact between these authors and contemporary Judaism, the arguments they used quickly become standardised and predictable, following well-established themes, and extend from explicit polemic to homiletic, exegetical and liturgical rhetoric."6 Theological stereotypes and current challenges, "image and reality," as Lieu entitles her study, shape the Christian stance toward Judaism. The result is not a uniform image but "multiple images, sometimes overlapping, sometimes contradictory."7

In this essay, I present two examples out of this multifaceted panorama of texts dealing with Jews and Judaism in connection with patristic interpretation of the Bible, one from Origen and the other from Ephrem. Origen, ${ }^{8}$ born in Alexandria around 185 C.E., was a prolific writer and occupied himself intensively

3 For a critical perspective, cf. S. Sandmel, "Parallelomania,” Journal of Biblical Literature 81 (1962): 1-13.

4 According to a definition by Johannes Heil, anti-Judaism is a theological concept, which is directed against Judaism as a whole and maintains the spiritual inferiority of Judaism and at the same time, of course, the spiritual superiority of Christianity. J. Heil, “'Antijudaismus' und 'Antisemitismus': Begriffe als Bedeutungsträger,” Jahrbuch für Antisemitismusforschung 6 (1997): 93-114, here 105-6: "Zu sprechen ist von Antijudaismus, sofern das gegen das Judentum als Ganze gerichtete theologische Konzept von der spirituellen-und daraus gefolgert rechtlich-sozialen-Inferiorität der Juden im Vergleich zum 'neuen Israel', d. h. den Christen als Trägern des 'neuen Bundes' gemeint ist.” This last point is the crucial point of the whole problem: anti-Judaism often functions as a means to corroborate one's own superiority, identity, and even right to exist.

5 Lieu, Image and Reality, 1.

6 Ibid., 4.

7 Ibid., 18.

8 For Origen's life and work, cf. H. J. Vogt, “Origen of Alexandria," in Handbook of Patristic Exegesis: The Bible in Ancient Christianity, ed. C. Kannengiesser (Leiden: Brill, 2004), 1:536 - 74; J. A. McGuckin, ed., The Westminster Handbook to Origen (Louisville: Westminster John Knox, 2004). 
with biblical interpretation. He wrote commentaries, homilies, and scholia, of which only a small part has been transmitted and preserved until today. Origen preached and wrote in Greek, but most of his works only survived in the Latin translations made by Rufinus and Jerome. Origen spent the last two decades of his life in Caesarea in Palestine where the bishop commissioned him to preach. The homilies on the Old Testament, including those on the book of Exodus, were held probably between 245 and 250. Origen died in Caesarea around 253 from the consequences of torture he had suffered during a persecution of

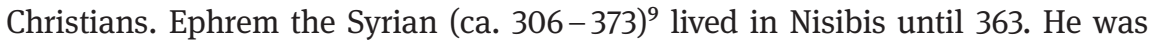
an active teacher, catechist, exegete, and poet of liturgical texts. Due to political circumstances (the Roman emperor transferred Nisibis to the Persians), many Christians left Nisibis. Ephrem took residence in Edessa where he continued his activities. Ephrem wrote in his mother tongue, Syriac. His commentaries on Genesis and Exodus are extant in their original Syriac version. They were written in Edessa after 363. A large portion of his work consists of poetic texts, usually called "hymns" (memre and madrashe in Syriac), which were composed for liturgical purposes. These texts, being interpretations of Scripture, are rather specific in genre, style, content, and above all, in their rhetorical purpose. ${ }^{10}$ Origen and Ephrem were prolific preachers and exegetes. Both lived in towns where a degree of contact with Jews was unavoidable. Both were engaged in eager discussions with "other" doctrines and practices. Their geographical, cultural, and political situations, however, differed from each other, as did their ecclesiastical position and the development of Christian doctrine. ${ }^{11}$ In the following discussion, the interpretations of Exodus 1-2 by Origen and Ephrem will be presented as examples of two differing Christian ways of biblical interpretation. ${ }^{12}$ Both authors, on the one hand, owe much to Jewish biblical interpretation, and on the other, express their anti-Jewish attitude in this context.

9 For Ephrem's life and work cf. S. H. Griffith, "Ephraem the Exegete (306-373): Biblical Commentary in the Works of Ephraem the Syrian," in Handbook of Patristic Exegesis: The Bible in Ancient Christianity, ed. C. Kannengiesser (Leiden: Brill, 2004), 2:1395-428; A. Friedl, "Ephräm der Syrer,” in Syrische Kirchenväter, ed. W. Klein (Stuttgart: Kohlhammer, 2004), 36-56.

10 Cf. S. A. Harvey, "Spoken Words, Voiced Silence: Biblical Women in Syriac Tradition," Journal of Early Christian Studies 9, no. 1 (2001): 105-31; Griffith, "Ephraem,” 2:1402. Griffith, "Ephraem," 2:1404 mentions "Ephraem's conviction that the heart of his scriptural commentary is to be found in his liturgical compositions."

11 Ephrem preaches after the council of Nicaea (325) and fervently defends its decisions.

12 The focus on Exod 1-2 is due to my project "The Saved Saviour: Exo 1-2 in Patristic and Rabbinic Interpretation,” financed by the “Austrian Science Fund” (P 28441-G24). 


\section{Origen}

Origen's second homily on Exodus ${ }^{13}$ provides the first example for this study. ${ }^{14}$ This homily expounds the midwives episode and Moses' nativity story in Exod 1-2. In the fourth paragraph of this homily, Origen interprets the exposure of the newborn Moses on the Nile and his salvation by Pharaoh's daughter. Origen understands Moses as "the law." 15 In his perspective, the law has to be understood spiritually, as he already states in his introductory remarks (referring to Rom 7:14). ${ }^{16}$ Pharaoh's daughter is identified as the "Church which is gathered from the Gentiles." ${ }^{17}$ This identification of Pharaoh's daughter is motivated by Origen's aim "to edify the church"-as he says-and is backed by a quotation from Psalm $45 .^{18}$ Origen relates her coming to the water of the Nile to baptism. Thus, she has left her father, Pharaoh, who represents evil or even the devil. As a small child, Moses was nourished by his own family. But his mother, the synagogue, put him into a basket and exposed him. For Origen, this means that the law was concealed until Pharaoh's daughter, the gentile church, found it and opened it. Thus, the veil was removed (allusion to 2 Cor 3:14-15). Only then was Moses able to grow up, because the church accepted the law

13 Edition of the Latin text: W. A. Baehrens, Origenes Werke: Homilien zum Hexateuch in Rufins Übersetzung, vol. 1: Die Homilien zu Genesis, Exodus und Leviticus (Leipzig: Hinrichs, 1920); English translation: R. E. Heine, ed., Origen: Homilies on Genesis and Exodus (Washington: Catholic University of America Press, 1982).

14 For Origen's relation to the Jews and to Jewish biblical interpretation, cf., for example, G. Bardy, “Les traditions juives dans l'œuvre d'Origène,” Revue biblique 34 (1925): 217-52; J. A. McGuckin, "Origen on the Jews," in Christianity and Judaism: Papers Read at the 1991 Summer Meeting and the 1992 Winter Meeting of the Ecclesiastical History Society, ed. D. Wood (Oxford: Blackwell, 1992), 1-13; N. R. M. de Lange, Origen and the Jews: Studies in Jewish-Christian Relations in Third-century Palestine (Cambridge: Cambridge University Press, 1976); N. R. M. de Lange, “Origen and the Jewish Bible Exegesis," Journal of Jewish Studies 22 (1971): 31-52; N. R. M. de Lange, "Origen and the Rabbis on the Hebrew Bible," Studia Patristica 14 (1976): 117-21; J. S. O’Leary, “The Recuperation of Judaism," in Origeniana Sexta: Origène et la Bible/Origen and the Bible, ed. G. Dorival and A. Le Boulluec (Leuven: University Press, 1995), 373-79; Schreckenberg, Adversus-Judaeos-Texte, 228-35; A. Tzvetkova-Glaser, "Polemics against JudeoChristian Practices in Origen's Homilies,” Studia Patristica 46 (2010): 217-22.

15 Origen, Hom. Exod. 2.4: "Moyses quia lex appellatur, in multis locis iam saepe dissertum est." (Baehrens, Origenes Werke, 160).

16 Cf. Origen, Hom. Exod. 2.1. Cf. Rom 7:14: "the law is spiritual.” All English Bible quotations in this article are from the JPS translation.

17 Origen, Hom. Exod. 2.4; Heine, Origen, 246.

18 Psa 45:11: "Hearken, O daughter, and consider, and incline thine ear; forget also thine own people, and thy father's house." 
and understood it in the right way, that is, spiritually. Furthermore, Origen allegorically interprets the wages that Pharaoh's daughter gives to Moses' mother: The synagogue receives the release from idolatry from the church-as a payment for nurturing Moses, the law, in his childhood-a somewhat paradoxical idea. Subsequently, Origen maintains that the gentile Christians' father had been Pharaoh-that is, the devil. In accepting Christ, the Christians had turned away from their father. Like Pharaoh's daughter, they came to the river and received baptism. Pharaoh's daughter is thus the ancestress of all gentile Christians.

In this interpretation, Origen constructs three groups on different levels: The "we-group," who are Christians like himself, the Jews, and the pagans who are identified with evil. ${ }^{19}$ The pagans are identified as the Christians' opponents on the level of the narrative: the Egyptians who threaten the Hebrews in Egypt (with their king, the devil). The Hebrews, then, are identified with the Christian audience. There are in fact no Jews in Origen's interpretation of the Exodus narrative. This is due to the direct application of the biblical text to the situation of his contemporary audience. Since Exod 1-2 implies a dichotomic structure of Egyptian = evil and Hebrew = good, there is no room for a third party. By claiming the Scriptural narrative for Christians, the Jews disappear from the story. ${ }^{20}$ The only exception is Moses' mother who is blamed for hiding and exposing Moses, the spiritual law.

The group, which Origen directly addresses, is the "we-group." ${ }^{21} \mathrm{He}$ is part of this group himself. Of course, these people are Christians. But this is not enough: what is decisive for Christians is their spiritual understanding of Scripture. In the introductory paragraph of this homily, Origen polemicizes against other Christians who are "friends of the letter and do not think that the Law is spiritual and is to be understood spiritually."22 This group is opposed to the "we-group": "But we" (sed nos), Origen continues, understand all these things to have happened in the interior of every Christian. His Christian interpretation includes two refer-

19 For an analysis of this interpretation technique and the identifications of biblical characters and groups with Origen's contemporaries, cf. A. Siquans, "Origen's Fifth Homily on Exodus: A Narratological Approach to Ancient Biblical Interpretation,” Biblical Reception 3 (2014): 291-307. 20 However, the dichotomic pattern is not strictly maintained throughout the narrative: There is an Egyptian princess who saves the Hebrew baby. And already in Exod 2:13-14, there are two Hebrews fighting each other and repudiating Moses.

21 See also A. Siquans, "Macht und Geschlecht in Ex 1-2 in der Auslegung von Origenes und Exodus Rabbah," in Macht und Machtkritik: Beiträge aus feministisch-theologischer und befreiungstheologischer Perspektive. Dokumentation des 4. internationalen Workshops "Kontextuelle befreiende Theologien,” ed. G. Prüller-Jagenteufel, R. Perintfalvi, and H. Schelkshorn (Aachen: Mainz, 2018), 124-34.

22 Origen, Hom. Exod. 2.1; Heine, Origen, 240. 
ences: the church, that is, the Christian community, and the individual with his/ her interior struggle for virtue and against evil.

The Christian and the "Jewish" groups oppose each other on the level of reading the Scriptures. All who do not interpret Scripture in a spiritual sense are the opponents of the "we-group," and according to Hom. Exod. 2.4, these are the Jews. Thus, Origen identifies "spiritual" with "Christian" and "literal” or non-spiritual with "Jewish." Moses' mother, the synagogue, did not recognize the law in its spiritual sense. This also means that the Jews do not correctly understand their own law and their own Scriptures. Two aspects are implied in this reasoning: First, the Jews are not completely evil and completely different from the Christians; there is some common ground and boundaries that cannot easily be defined. Second, the Jews have a wrong understanding of the Scriptures, and thus their interpretation and their practice must be rejected (and so must the practice and interpretation of all Christians who use the same method to interpret the Bible).

This reasoning is corroborated by other texts with more explicit statements concerning this subject. In the seventh homily on Numbers, interpreting Num 12, Origen clearly defines where the boundaries must be set:

But I think that it is not merely that first people [i.e., the Jews] nor the heretics alone, whom we have mentioned above, who "speak disparagingly of Moses" [Num 12:8]. For all who understand the writings of Moses badly and those who receive the spiritual law in a carnal fashion also speak disparagingly of Moses, because from words that proceed from the Spirit, they teach people in a fleshly way. ${ }^{23}$

In this text, the abovementioned idea is expressed more explicitly. To be Jewish is not necessarily defined by belonging to a certain religious group or a certain ethnicity but by a particular way of reading the Bible. ${ }^{24}$ The consequence is that "Jewish" is synonymous with "not spiritual," thus fleshly and carnal. Moreover, Jews are close to heretics in Origen's view.

Jews in these texts are "the religious others" who are very close to oneself. We know that in those centuries, Christian bishops or preachers often com-

23 Origenes, Hom. Num. 7.1.3: "Ego autem puto quod non solus ille populus prior neque soli haeretici, de quibus supra memorauimus 'detrahat de Moyse', sed et omnis qui scripta eius male intellegit et qui spiritalem legem carnaliter suscipit, 'Moysi derogat', quia de uerbis spiritus carnaliter homines docet.” The quotation refers to Num 12:8. English: T. P. Scheck, trans., Origen: Homilies on Numbers (Downers Grove: IVP Academic, 2009), 25.

24 Cf. Lange, Origen and the Jews, 104-6. 
plained that Christians went to synagogues and participated in Jewish festivals. ${ }^{25}$ This is the very reason why the polemic is so sharp-because the boundary is not clear to every Christian. But according to Origen, this is the boundary between heaven and earth.

Nevertheless, Origen's biblical interpretation owes a lot to the exegesis of Philo of Alexandria. ${ }^{26}$ Origen knows that Philo is a Jew, yet Philo is an allegorical interpreter of the Bible. Therefore, by Origen's implicit definition, Philo's exegesis is not "Jewish." Philo himself sometimes polemicizes against those who reject an allegorical interpretation of Scripture. However, he insists on the observance of the Mosaic Law. Origen only borrows the allegorical interpretation from Philoeven detailed explanations-and "Christianizes" it. ${ }^{27}$ Thus, there is again common ground on the one hand and differentiation and alienation on the other.

Origen's worldview is determined to a high degree by a dichotomic order, opposing heaven and earth, spirit and flesh, male and female, good and evil, Christian and Jewish, etc. However, his dichotomic worldview is not as clear as one might think at first glance. Origen's texts leave room for nuances. Although for him all non-Christians belong to the earthly, fleshly pole of the cosmological hierarchy, he concedes differences between pagans, Jews, and heretics and between different Christian groups. Undifferentiated polemic is primarily due to the moral focus of his homilies, which intends to warn the audience not to fall into any error or deviate from the right Christian way of life. Origen is quite anxious about the possible return of his Christian flock to a pagan or Jewish lifestyle.

Origen is one of the few patristic exegetes who explicitly refers to Jews as the source of particular interpretations. He uses Jewish interpretations, and at the same time, he rejects "the Jews" as others whose religious practice and biblical interpretation should be avoided.

25 So did Origen (e.g., Hom. Lev. 5), John Chrysostom (e.g., Adv. Jud. 1.1.5), and others. Cf. Simon, Verus Israel, 306-38; for Chrysostom, cf. also W. Kinzig, “'Non-Separation': Closeness and Co-operation between Jews and Christians in the Fourth Century," Vigiliae Christianae 45 (1991): 27-53; R. L. Wilken, John Chrysostom and the Jews: Rhetoric and Reality in the Late 4th Century (Berkeley: University of California Press, 1983), 75-76.

26 Cf. D. T. Runia, Philo in Early Christian Literature: A Survey (Assen: Van Gorcum/Minneapolis: Fortress, 1993), 157-83.

27 In contrast to other Christian interpreters, as for instance Ephrem or Gregory of Nyssa in his Life of Moses, Origen's interpretation does not show parallels to Philo's more literal presentation in the Vita Mosis but only to the allegorical commentaries. 


\section{Ephrem the Syrian}

The case of Ephrem the Syrian is even more problematic. His anti-Judaism has frequently been discussed. ${ }^{28}$ However, his biblical interpretations are at the surface very much like Jewish interpretations, similar to Targum and midrash. ${ }^{29}$ The interpretation of Exodus 1 and 2 is a literal interpretation of the biblical text. ${ }^{30}$ It contains no Christological or allegorical/typological readings. ${ }^{31}$ Ephrem also presents traditions otherwise known from Philo, Josephus, and the later midrash Tanhuma. These parallels are interpreted differently by scholars. Sten Hidal, for instance, is skeptical about the direct influence of Jewish sources on Ephrem.

28 Cf., for example, K. McVey, “The Anti-Judaic Polemic of Ephrem Syrus' Hymns on the Nativity," in Of Scribes and Scrolls: Studies in the Hebrew Bible, Intertestamental Judaism, and Christian Origins, ed. H. W. Attridge, J. J. Collins, and T. H. Tobin (Lanham: University of America Press, 1990), 229-40; C. Shepardson, "Anti-Jewish Rhetoric and Intra-Christian Conflict in the Sermons of Ephrem Syrus,” Studia Patristica 35 (2001): 502-7; C. Shepardson, Anti-Judaism and Christian Orthodoxy: Ephrem's Hymns in Fourth-century Syria (Washington: Catholic University of America Press, 2008); Schreckenberg, Adversus-Iudaeos-Texte; S. Kazan, "Isaac of Antioch's Homily against the Jews," Oriens Christianus 45 (1961): 30 -53; 46 (1962): 87-98; 47 (1963): 89-97; 49 (1965): 57-78; A. P. Hayman, “The Image of the Jew in the Syriac Anti-Jewish Polemical Literature," in “To See Ourselves as Others See Us": Christians, Jews, "Others” in Late Antiquity, ed. J. Neusner and E. S. Frerichs (Chico: Scholars Press, 1985), 423-41; for Ephrem see especially 427-33 (Hayman explicitly notes Ephrem's personality as a relevant aspect of his antiJewish invectives: “But it also owes a lot to Ephraem's own fiery temperament, for he reacted to other threats to the Church [from Bardaisanites, Marcionites, Manicheans, etc.], with the same degree of virulence and abuse.”); H. J. W. Drijvers, “Jews and Christians at Edessa," Journal of Jewish Studies 36 (1986): 88-102; K. H. Kuhlmann, "The Harp out of Tune: The Anti-Judaism/ anti-Semitism of St. Ephrem,” The Harp 4 (2004): 177-83; E. Narinskaya, Ephrem, A "Jewish" Sage: A Comparison of the Exegetical Writings of St. Ephrem the Syrian and Jewish Traditions (Turnhout: Brepols, 2010). Narinskaya's attempt to portray Ephrem as not anti-Jewish but friendly toward Jews does not convince the reader.

29 Cf., for example, D. Gerson, "Die Commentarien des Ephraem Syrus im Verhältnis zur jüdischen Exegese: Ein Beitrag zur Geschichte der Exegese,” Monatsschrift für Geschichte und Wissenschaft des Judentums 17 (1868): 15-33, 64-72, 98-109, 141-9; S. P. Brock, “Jewish Traditions in Syriac Sources,” Journal of Jewish Studies 30 (1979): 212-32; S. P. Brock, “Some Syriac Legends Concerning Moses," Journal of Jewish Studies 33 (1982): 237-55. According to Brock, “Jewish Traditions," 218, the knowledge of Targum tradition is clearly discernible in Aphraates and Ephrem, especially in his commentary on Genesis.

30 Edition of the Syriac text with Latin translation: R.-M. Tonneau, ed., Sancti Ephraem Syri in Genesim et in Exodum Commentarii (Louvain: L. Durbecq, 1955); English translations: K. McVey, ed., St. Ephrem the Syrian: Selected Prose Works (Washington: Catholic University of America Press, 1994); A. Salvesen, trans., The Exodus Commentary of St. Ephrem (Piscataway: Gorgias, 2011).

31 There are such readings in the exegesis of Exod 12, however. 
Ephrem, in contrast to Origen and Jerome, never refers to the Jewish origin of an interpretation. Because of the anti-Judaism in his different writings, Hidal assumes that Ephrem became acquainted with these interpretations as distinct from Jewish ones. ${ }^{32}$ I think this is not necessarily the case. In all likelihood, he did not perceive these interpretations as exclusively Jewish but as a common type of interpretation. Similarly, Alison Salvesen states that "Syriac-speaking Jews and Christians shared a language, traditions, and Scripture that gave some common elements to their respective worship services" ${ }^{3}$-and, I wish to add-to their respective Scriptural interpretation. Brock mentions three ways in which Ephrem learned about Jewish traditions: the Peshitta, apocrypha and pseudepigrapha, and independently of these, oral or written sources. ${ }^{34}$ Drijvers is convinced that Ephrem had personal contact with Rabbis. ${ }^{35}$ Narinskaya maintains that there was a common tradition of biblical exegesis of Semitic origin, which Ephrem knew and used. ${ }^{36}$ Today, we can no longer be sure about the ways Ephrem became acquainted with Jewish exegetical traditions, and we should not draw too far-reaching conclusions about contacts with Rabbis, for example. What is certain, indeed, is Ephrem's remarkable proximity to rabbinic interpretations of the Bible.

Therefore, it is quite surprising to find vehement anti-Jewish invectives in his hymns and sermons. I want to quote just one example out of numerous possibilities. Characteristic of Ephrem is his thinking and writing in contrasting opposites: light and dark, sweet and bitter, etc. He contrasts "the people," that is, the Jews, with "the peoples," that is, all other peoples who have come to the church. The following passage describes the Jews as foolish. Although they have the Scriptures, they do not understand them:

The People have the voice and the reading; the peoples have the shining forth and the explanation. They have the books and we have the deeds; they have the branches and we

32 Cf. S. Hidal, Interpretatio syriaca: Die Kommentare des heiligen Ephräm des Syrers zu Genesis und Exodus mit besonderer Berücksichtigung ihrer auslegungsgeschichtlichen Stellung (Lund: Gleerup, 1974), 131-38.

33 Shepardson, "Anti-Jewish Rhetoric," 41.

34 Cf. Brock, "Jewish Traditions," 231.

35 Drijvers, "Jews," 101. He also mentions apocryphal and pseudepigraphical texts as a possible source.

36 Narinskaya, Ephrem, 178: "There may have been a tradition of biblical exegesis common to both Jews and Christians, of Semitic origin. This tradition could have involved work with Semitic languages, i.e. Hebrew, Aramaic and Syriac. Later, this tradition could have been developed further by rabbinical exegesis to form the basis of various later Jewish compilations like the Talmud, and classical Midrashim." 
their fruits. The scribes read in books; the magi saw in actions the flash of that reading.... The simple believers recognized two advents of Christ, but the foolish scribes were not aware of even one advent. Yet the peoples received life from one and there at the other they will be revived. The one advent scattered the People whose understanding was blind; the second will blot out its memory. ${ }^{37}$

Where does this hostile attitude towards the Jews come from? Alfred Friedl mentions several possibilities: the strong presence of Jews in Nisibis and Edessa; their better social and political situation; their privileged position during the rule of the Seleucids; the strong ascetic orientation of Syriac Christianity as opposed to Judaism; the suspicion of many Christians toward Jewish religious practice; and the theological tradition of Judaism as antipode of Christian identity. ${ }^{38}$ Ephrem's anti-Judaism is part of a then already long-standing tradition in Christianity. He also draws clear boundaries between "us" and "them." ${ }^{39}$ Christine Shepardson concludes: "Ephrem thus distances the category 'Jew' from that of 'Christian,' making the Jews an incompatible 'other' to the Christian self." ${ }^{40}$ It is important to be aware of the character and purpose of these kinds of texts: they are liturgical rhetoric aimed at convincing the audience to distance themselves from "deviant" positions, represented by "the Jews."

Shepardson demonstrates that Ephrem uses his anti-Jewish rhetoric in many (or most) cases for the defense against or attack of Christian opponents, namely people who do not follow the Nicene doctrine. Nevertheless, their anti-Jewish thrust remains. Again, the problem is that of setting clear boundaries. Shepardson writes about the controversy about the council of Nicaea:

37 Ephrem, De Nativitate 24.4.11. E. Beck, ed., Des Heiligen Ephraem des Syrers Hymnen de Nativitate (Epiphania) (Louvain: Secretariat of the CSCO, 1959), 1:122-24. English translation: K. McVey, Ephrem the Syrian: Hymns (New York: Paulist Press, 1989), 63-217. Quotation from Shepardson, Anti-Judaism, 55.

38 Cf. Friedl, "Ephräm," 54-55. With the acceptance of multiple causes and motivations for anti-Jewish polemic, an age-old discussion between strict alternatives can be laid aside. The discussion exists between authors who explain anti-Judaism as a merely theological necessity, as for instance already S. Krauss, "The Jews in the Works of the Church Fathers IV," Jewish Quarterly Review 6, no. 1 (1893): 82-99; and concerning Ephräm 88-99: "His resentment seems to have been aroused and stimulated by the marvellous power of resistance shown by the old creed" (89), and authors who presuppose a strong Jewish missionary activity, as for example, Kazan, "Isaac." Several aspects, which may change in the course of time, continuously interact. See also A. Siquans, "Anti-Jewish Interpretation of the Bible with the Church Fathers," in AntiSemitism and the Bible, ed. A. Lange, S. Gillmayr-Bucher, A. Colella, and L. Stuckenbruck (Göttingen: Vandenhoeck \& Ruprecht, forthcoming).

39 Cf. Shepardson, Anti-Judaism, 151.

40 Ibid., 39. 


\begin{abstract}
As with the problem of Judaizing, so too with this controversy Ephrem criticizes in an effort to make his congregation conform to the boundaries of Nicene orthodoxy. Just as he draws clear boundaries for their behaviour with respect to Judaizing and Nicene orthodoxy, so too, he delineates clear lines between orthodox and heretical teachings about God and God's Son, fighting not against a separate Nisibene or Edessene "Arian" church, but against the non-Nicene teachings currently dominating the empire that might infiltrate his community and lead his flock astray. Thus while Ephrem seems to warn against "real" fourth-century teachings, the rhetorical opponents whom his poetry paints are again "image" as well as "reality," a constructed clear threatening and dangerous "other" with which he attempts to frighten his listeners to take shelter behind the safe walls of Nicene orthodoxy. ${ }^{41}$
\end{abstract}

What Shepardson says about the Christian anti-Nicene opponents is likewise valid for Jews. In his hymns and sermons, Ephrem constructs Jews as the threatening and disgusting "others," in order to keep his Christian community away from them, their teaching, and their practice. Obviously many Christians in Nisibis and Edessa did not catch the importance of the differences that Ephrem claims and the boundaries he draws. It is likely that for many people, these boundaries did not exist or at least did not matter. ${ }^{42}$ Thus, it was all the more important to establish and make clear these boundaries. The setting of boundaries is most necessary in demarcation from the closest neighbors: "The problem is not alterity, but similarity-at times, even identity."43

\title{
Conclusion
}

The presented examples of patristic biblical interpretation may illustrate the complex attitude of Christian interpreters to Jews and Jewish interpretations. Origen and Ephrem continue already established theological stereotypes against the Jews and adapt them to their present reality. They use Jewish exegetical traditions, sometimes "Christianizing" them and at the same time polemicizing against Judaism. I want to add two remarks in order to shed some more light on this evidence. Firstly, both Origen and Ephrem are preachers. They play a cru-

41 Shepardson, Anti-Judaism, 153.

42 J. C. Paget, “Anti-Judaism and Early Christian Identity,” Zeitschrift für Antikes Christentum 1 (1997): 195-225 states that at a popular level "absolute distinctions between Judaism and Christianity were likely to be less clear" (211). Cf. Kinzig, "Jews and Christians," 29: "on the level of popular piety there was a wide overlap between Church and Synagogue at least until the end of the fourth century, but probably far beyond" (emphasis by Kinzig).

43 J. Z. Smith, "What a Difference a Difference Makes," in "To See Ourselves as Others See Us": Christians, Jews, "Others” in Late Antiquity, ed. J. Neusner and E. S. Frerichs (Chico: Scholars Press, 1985), 3-48, here 47. 
cial part in the formation of their audiences' ideas about themselves and others: Who are "we," and who are the others? What is problematic about "them," and why should their teaching or their practice be avoided? They vilify the others, including the Jews. The greater the perceived proximity to another group, the greater the vehemence of the polemic against it. ${ }^{44}$ Just because the Jews were not absolutely "different," but, on the contrary, very close, at least at the time of our authors, they had to be construed as being absolutely "different" in order to clarify, delimit, and affirm their own Christian identity. The roots of anti-Judaism in early Christian interpretations of the Bible are a situation of insecurity about their own identity (vis-à-vis Jews, pagans, and so-called heretics). Furthermore, they perhaps also reflect the challenges of the minority situation of the Christians, as well as the lack of clear boundaries. This leads to a polemical rhetoric, often including verbal violence. This theological verbal violence becomes threatening for Jews as soon as Christians become a majority and are in a position of political power. Then, the boundary between merely theological verbal violence and the exertion of physical violence is often too fragile and can easily be transgressed. This implies a high responsibility of preachers, teachers, and all persons who speak on behalf of religious groups. Secondly, Origen and Ephrem both use thought patterns of dichotomy and contrast, albeit in different ways. In such systems, there is no alternative beyond light and darkness, good and evil.

However, an alternative "in between" does exist insofar as there is a certain diversity in every community and society. The question is: who is defined as the "other" one, and how are certain forms of "otherness" or diversity evaluated? A dichotomic worldview is not able to integrate ambivalent phenomena, which are normal facts of life. The problem is not diversity per se-diversity and "otherness" simply exist. Rather, the problem is the evaluation and definition of these facts. Every community has to answer the question of the phenomena they experience as acceptable or not. Patristic biblical interpretation answered this question to the disadvantage of the Jews. This direction was retained throughout the centuries.

Many of the topoi against the Jews constructed by the church fathers soon became conventional and played a prominent role in later antisemitism. The first step towards avoiding the perpetuation of these concepts is critically revealing their way of construing identity and its ongoing impact on contemporary thought about Jewishness. Furthermore, alternative ways of defining identity

44 Cf. Smith, "What a Difference," 15: "Such distinctions are found to be drawn most sharply between 'near neighbors,” and they are "essentially political.” 
have to be developed-alternatives that do not operate in dichotomic patterns and do not define identity in terms of uniformity but appreciate diversity. Diversity exists; the "other" one simply exists, even nearby. Boundaries are necessary and discussions about identity are unavoidable as well. The challenge is to strengthen the own identity without denigrating others. Perhaps the patristic texts in their ambivalence and multiplicity can also provide evidence for this task.

Now what makes the inquiry into the reciprocal conceptions of Judaism and Christianity in these formative centuries critical? It is the simple fact that the developing theories of the other left a legacy, for both medieval and modern Western civilization, of not only intolerance but also restraint, not only a quest for universal conformity but also a capacity to sustain difference. ${ }^{45}$

Agnethe Siquans is Professor for Old Testament Studies at the Faculty of Catholic Theology at the University of Vienna. Her main research fields are intertextual exegesis of the Old Testament, the reception of Scripture in patristic writings, church fathers and rabbinic midrash, Jewish-Christians relations in Antiquity, and feminist exegesis of Scripture and early Christian writings.

\section{Bibliography}

Baehrens, Wilhelm Adolf. Origenes Werke: Homilien zum Hexateuch in Rufins Übersetzung 1: Die Homilien zu Genesis, Exodus und Leviticus. Leipzig: Hinrichs, 1920.

Bardy, Gustave. “Les traditions juives dans l'œuvre d’Origène.” Revue biblique 34 (1925): 217-52.

Beck, Edmund, ed. Des heiligen Ephraem des Syrers Hymnen de Nativitate (Epiphania). Louvain: Secretariat of the CSCO, 1959.

Brock, Sebastian P. “Jewish Traditions in Syriac Sources.” Journal of Jewish Studies 30 (1979): $212-32$.

Brock, Sebastian P. "Some Syriac Legends Concerning Moses." Journal of Jewish Studies 33 (1982): $237-55$.

Friedl, Alfred. "Ephräm der Syrer." In Syrische Kirchenväter, edited by Wassilios Klein, 36-56. Stuttgart: Kohlhammer, 2004.

Drijvers, Han J. W. "Jews and Christians at Edessa." Journal of Jewish Studies 36 (1986): $88-102$.

45 J. Neusner and E. S. Frerichs, eds., “To See Ourselves as Others See Us”: Christians, Jews, "Others" in Late Antiquity (Chico: Scholars Press, 1985), xiii. 
Gerson, David. "Die Commentarien des Ephraem Syrus im Verhältnis zur jüdischen Exegese: Ein Beitrag zur Geschichte der Exegese." Monatsschrift für Geschichte und Wissenschaft des Judentums 17 (1868): 15-33.

Griffith, Sidney H. "Ephraem the Exegete (306-373): Biblical Commentary in the Works of Ephraem the Syrian." In Handbook of Patristic Exegesis: The Bible in Ancient Christianity, edited by Charles Kannengiesser, 2:1395-428. Leiden: Brill, 2004.

Grypeou, Emmanouela and Helen Spurling, eds. The Exegetical Encounter between Jews and Christians in Late Antiquity. Leiden: Brill, 2009.

Harvey, Susan Ashbrook. "Spoken Words, Voiced Silence: Biblical Women in Syriac Tradition." Journal of Early Christian Studies 9, no. 1 (2001): 105-31.

Hayman, Andy P. "The Image of the Jew in the Syriac Anti-Jewish Polemical Literature." In "To See Ourselves as Others See Us": Christians, Jews, "Others" in Late Antiquity, edited by Jacob Neusner and Ernest S. Frerichs, 423-41. Chico: Scholars Press, 1985.

Heil, Johannes. “'Antijudaismus' und 'Antisemitismus:' Begriffe als Bedeutungsträger.” Jahrbuch für Antisemitismusforschung 6 (1997): 93-114.

Heine, Ronald E., ed. Origen: Homilies on Genesis and Exodus. Washington: Catholic University of America Press, 1982.

Hidal, Sten. Interpretatio syriaca: Die Kommentare des heiligen Ephräm des Syrers zu Genesis und Exodus mit besonderer Berücksichtigung ihrer auslegungsgeschichtlichen Stellung. Lund: Gleerup, 1974.

Hirshman, Marc. A Rivalry of Genius: Jewish and Christian Biblical Interpretation in Late Antiquity. Translated by Batya Stein. Albany: State University of New York Press, 1996.

Horbury, William. Jews and Christians in Contact and Controversy. Edinburgh: T\&T Clark, 1998.

Kamesar, Adam. "Rabbinic Midrash and Church Fathers." In Encyclopaedia of Midrash: Biblical Interpretation in Formative Judaism, edited by Jacob Neusner and Alan J. Avery-Peck, 20-40. Leiden: Brill, 2005.

Kazan, Stanley. "Isaac of Antioch's Homily against the Jews." Oriens Christianus 45 (1961): 30-53; 46 (1962): 87-98; 47 (1963): 89-97; 49 (1965): 57-78.

Kessler, Edward. "The Exegetical Encounter between the Greek Church Fathers and the Palestinian Rabbis.” Studia Patristica 34 (2001): 395- 412.

Kinzig, Wolfram. “'Non-Separation': Closeness and Co-operation between Jews and Christians in the Fourth Century." Vigiliae Christianae 45 (1991): 27-53.

Krauss, Samuel. "The Jews in the Works of the Church Fathers IV." Jewish Quarterly Review 6, no. 1 (1893): 82-99.

Krauss, Samuel and William Horbury. The Jewish-Christian Controversy: From the Earliest Times to 1789. Vol. 1: History. Tübingen: Mohr Siebeck, 1995.

Kuhlmann, Karl-Heinz. "The Harp out of Tune: The Anti-Judaism/anti-Semitism of St. Ephrem." The Harp 4 (2004): 177-83.

Lange, Nicholas R. M. de. "Origen and the Jewish Bible Exegesis." Journal of Jewish Studies 22 (1971): 31-52.

Lange, Nicholas R. M. de. Origen and the Jews: Studies in Jewish-Christian Relations in Third-century Palestine. Cambridge: Cambridge University Press, 1976.

Lange, Nicholas R. M. de. "Origen and the Rabbis on the Hebrew Bible." Studia Patristica 14 (1976): 117-21. 
Lieu, Judith M. Image and Reality: The Jews in the World of the Christians in the Second Century. Edinburgh: T\&T Clark, 1996.

McGuckin, John A. "Origen on the Jews." In Christianity and Judaism: Papers Read at the 1991 Summer Meeting and the 1992 Winter Meeting of the Ecclesiastical History Society, edited by Diana Wood, 1-13. Oxford: Blackwell, 1992.

McGuckin, John A., ed. The Westminster Handbook to Origen. Louisville: Westminster John Knox, 2004.

McVey, Kathleen E. “The Anti-Judaic Polemic of Ephrem Syrus' Hymns on the Nativity." In Of Scribes and Scrolls: Studies on the Hebrew Bible, Intertestamental Judaism, and Christian Origins Presented to J. Strugnell on the Occasion of His Sixtieth Birthday, edited by Harold W. Attridge, John J. Collins, and Thomas H. Tobin, 229-40. Lanham: University of America Press, 1990.

McVey, Kathleen E. Ephrem the Syrian: Hymns. New York: Paulist Press, 1989.

McVey, Kathleen, ed. St. Ephrem the Syrian: Selected Prose Works. Washington: Catholic University of America Press, 1994.

Narinskaya, Elena. Ephrem: A “Jewish" Sage: A Comparison of the Exegetical Writings of St. Ephrem the Syrian and Jewish Traditions. Turnhout: Brepols, 2010.

Neusner, Jacob, and Ernest S. Frerichs, eds. "To See Ourselves as Others See Us": Christians, Jews, "Others" in Late Antiquity. Chico: Scholars Press, 1985.

O’Leary, Joseph S. "The Recuperation of Judaism." In Origeniana Sexta: Origène et la Bible/Origen and the Bible, edited by Gilles Dorival and Alain Le Boulluec, 373-79. Leuven: Leuven University Press, 1995.

Paget, James Carleton. "Anti-Judaism and Early Christian Identity." Zeitschrift für Antikes Christentum 1 (1997): 195-225.

Porter, Stanley E. and Brook W. R. Pearson, eds. Christian-Jewish Relations through the Centuries. Sheffield: Sheffield Academic, 2000.

Runia, David T. Philo in Early Christian Literature: A Survey. Assen: Van Gorcum/Minneapolis: Fortress, 1993.

Salvesen, Alison, trans. The Exodus Commentary of St. Ephrem. Piscataway: Gorgias, 2011.

Sanders, Ed P. Jewish and Christian Self-Definition. 3 vols. Philadelphia: Fortress, $1980-1983$.

Sandmel, Samuel. “Parallelomania." Journal of Biblical Literature 81 (1962): 1-13.

Scheck, Thomas P., trans. Origen: Homilies on Numbers. Downers Grove: IVP Academic, 2009.

Schreckenberg, Heinz. Die christlichen Adversus-Judaeos-Texte und ihr literarisches und historisches Umfeld (1.-11. Jahrhundert). Frankfurt am Main: Peter Lang, 1995.

Shepardson, Christine C. "Anti-Jewish Rhetoric and Intra-Christian Conflict in the Sermons of Ephrem Syrus.” Studia Patristica 35 (2001): 502-7.

Shepardson, Christine C. Anti-Judaism and Christian Orthodoxy: Ephrem's Hymns in Fourth-century Syria. Washington: Catholic University of America Press, 2008.

Simon, Marcel. Verus Israel: A Study of the Relations between Christians and Jews in the Roman Empire (135-425), translated by Henry McKeating. Oxford: Oxford University Press, 1986.

Siquans, Agnethe. "Anti-Jewish Interpretation of the Bible with the Church Fathers." In Anti-Semitism and the Bible, edited by Armin Lange, Susanne Gillmayr-Bucher, Andrea Colella, and Loren Stuckenbruck. Göttingen: Vandenhoeck \& Ruprecht, forthcoming. 
Siquans, Agnethe. "Macht und Geschlecht in Ex 1-2 in der Auslegung von Origenes und Exodus Rabbah.” In Macht und Machtkritik: Beiträge aus feministisch-theologischer und befreiungstheologischer Perspektive. Dokumentation des 4. internationalen Workshops "Kontextuelle befreiende Theologien," edited by Gunter M. Prüller-Jagenteufel, Rita Perintfalvi, and Hans Schelkshorn, 124-34. Aachen: Mainz, 2018.

Siquans, Agnethe. "Origen's Fifth Homily on Exodus: A Narratological Approach to Ancient Biblical Interpretation." Biblical Reception 3 (2014): 291-307.

Smith, Jonathan Z. "What a Difference a Difference Makes." In "To See Ourselves as Others See Us": Christians, Jews, "Others" in Late Antiquity, edited by Jacob Neusner and Ernest S. Frerichs, 3-48. Chico: Scholars Press, 1985.

Stemberger, Günter. "Exegetical Contacts between Christians and Jews in the Roman Empire." In Hebrew Bible/Old Testament: The History of Its Interpretation. Vol. 1: From the Beginnings to the Middle Ages (until 1300), part 1: Antiquity, edited by Magne Sæbø, 569-86. Göttingen: Vandenhoeck \& Ruprecht, 1996.

Tonneau, Raymond M., ed. Sancti Ephraem Syri in Genesim et in Exodum Commentarii. Louvain: L. Durbecq, 1955.

Tzvetkova-Glaser, Anna. "Polemics against Judeo-Christian Practices in Origen's Homilies." Studia Patristica 46 (2010): 217-22.

Visotzky, Burton L. Fathers of the World: Essays in Rabbinic and Patristic Literatures. Tübingen: Mohr, 1995.

Vogt, Hermann Josef. "Origen of Alexandria." In Handbook of Patristic Exegesis: The Bible in Ancient Christianity, edited by Charles Kannengiesser, 1:536-74. Leiden: Brill, 2004.

Wilken, Robert Louis. John Chrysostom and the Jews: Rhetoric and Reality in the Late 4th Century. Berkeley: University of California Press, 1983. 